\title{
ACP1 Gene
}

National Cancer Institute

\section{Source}

National Cancer Institute. ACP1 Gene. NCI Thesaurus. Code C88195.

This gene is involved in both the metabolism of flavinoids and the posttranslational modification of proteins. 